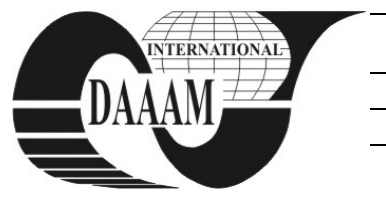

Annals of DAAAM for 2011 \& Proceedings of the 22nd International DAAAM Symposium, Volume 22, No. 1, ISSN 1726-9679 ISBN 978-3-901509-83-4, Editor B. Katalinic, Published by DAAAM International, Vienna, Austria, EU, 2011 Make Harmony between Technology and Nature, and Your Mind will Fly Free as a Bird Annals \& Proceedings of DAAAM International 2011

\title{
OPTIMAL TIME OF BLOWING THE OXYGEN IN THE DECARBONIZATION OF CAST IRON IN STEEL IN METAL JANJEVO
}

\author{
ZABELI, M[uharrem]; TERZIQI, A[vni] K[ahriman] \& BAJRAKTARI, B[ekim] V[eli]
}

\begin{abstract}
Melting of metal scrap from the steel and cast-iron in cupola furnace with aim of providing of semi-product and final product with the content of cast-iron is shown as successful process in economic and industrial aspect. A greater request for production of other details from the steel has performed the need of examining the possibility for refinery of cast iron-liquid in auxiliary furnace where can be done the process of decarbonization with pure oxygen blowing in melted cast iron. The main processes which are treated in this work are: determination of optimal time and quality of oxygen which have to be blown in a fixed quantity of liquid cast-iron, examination of possibility of connected elements as: $\mathrm{Ni}, \mathrm{Cr}, \mathrm{Mo}$, etc, and depending from carbon quantity in refined steel to do the determinations of optimal parameters of whole process words Key words: auxiliary furnace, cast iron, steel, smelting, decarbonization
\end{abstract}

\section{INTRODUCTION}

Based on the tremendous amount of metal waste consisting of cast iron and steel in Kosovo and in the process smelting them into the furnace cupola in order to obtain the liquid coast iron, and that this process has been shown successful in economic and industrial terms, is a need for examining the possibility of decarbonization of the liquid cast iron produced in the cupola furnace, with auxiliary furnace application bulge pure oxygen in molten cast iron (Eric, 2009). Cast Iron melted by cupola furnace exit hole through which flows into the channel makes possible the movement of the molten cost iron to the furnace auxiliary bathroom.

The auxiliary furnace capacity is $300-400 \mathrm{~kg}$. Upon reaching the bathroom of auxiliary oven with melted cast iron pouring hole closes the oven cupola to another load and then placed through the particular mechanism for blower pure oxygen in molten cast iron and oxygen begins to blow until reaching decarbonization.

In addition the paper will be descriptions ranging from analysis of the composition of the three loads of cost iron produced in the cupola furnace, then identify the amount and timing of bulge pure oxygen in molten cast iron, a description of the analysis of the composition of some auxiliary loads in the furnace after decarbonization and all these optimization of this whole process.

\section{ANALYSIS OF CAST IRON BEFORE REFINING}

Laboratory Analysis Company of Janjeva. After analyzing with the atomic absorber is determinate composition of three samples of cost iron (Table 1).

\begin{tabular}{|l|c|c|c|c|}
\hline Composition & $\mathrm{C}(\%)$ & $\mathrm{Si}(\%)$ & $\mathrm{Mn}(\%)$ & $\mathrm{P}(\%)$ \\
\hline Sample 1 & 4.4 & 1.6 & 1.2 & 0.6 \\
\hline Sample 2 & 4.2 & 1.5 & 1.3 & 0.5 \\
\hline Sample 3 & 4.3 & 1.7 & 1.3 & 0.5 \\
\hline
\end{tabular}

Tab. 1. The composition of three samples of cost iron
For our experimental work is important is the amount of carbon which auxiliary furnace should be reduced as far as marks (types) of the special steels.

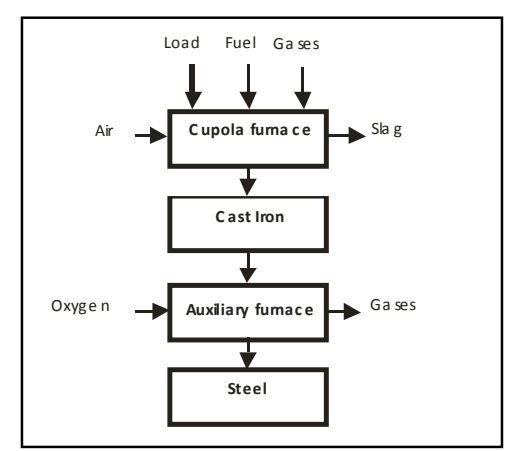

Fig. 1. Schematic presentation of the all process

View of the cupola furnace and auxiliary furnace (fig. 2 and fig.3).

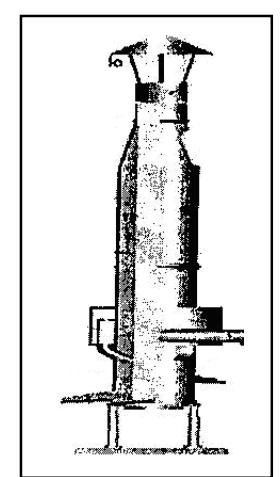

Fig. 2. Cupola furnace

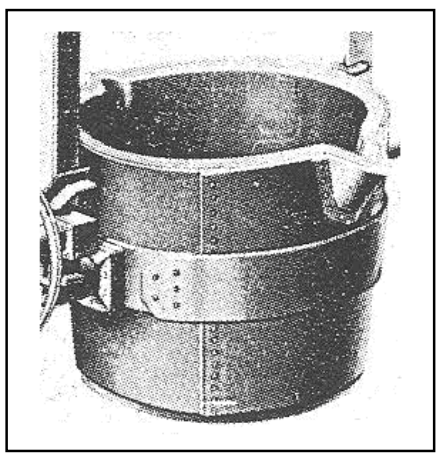

Fig. 3. Auxiliary furnace

Auxiliary furnace inside (basement and bathroom) is masonry with fireproof material of refractory bricks chamotte have circular shape, while the external mantle of the furnace is constructed from galvanized steel with thickness $10 \mathrm{~mm}$. In 
wrapping is set special mechanism for lifting and emptying of metal (steel) melt after decarbonization.

\section{WORKING PARAMETERS OF AUXILIARY FURNACE}

- The capacity of auxiliary furnace for one load is $400 \mathrm{~kg}$.

- Temperature of the cast iron-poured in the bathroom of auxiliary furnace is $1320{ }^{\circ} \mathrm{C}$ (Schuman, 1985)

- The capacity of blower is $1.2 \mathrm{~m}^{3} / \mathrm{min}$

- The blowing time of oxygen for four loads given in Table 2.

\begin{tabular}{|l|c|c|c|c|}
\hline Number of loads & 1 & 2 & 3 & 4 \\
\hline Time of blowingof $\mathrm{O}_{2}(\mathrm{~min})$ & 10 & 15 & 20 & 25 \\
\hline
\end{tabular}

Tab. 2. Blowing time for four loads of Oxygen

The main reactions taking place in the bathroom of the oven are (Bugayev \& Ivan, 2001):

$$
\begin{gathered}
\mathrm{C}+0.5 \mathrm{O}_{2}=\mathrm{CO} \\
\mathrm{CO}+0.5 \mathrm{O}_{2}=\mathrm{CO}_{2} \\
\mathrm{C}+\mathrm{O}_{2}=\mathrm{CO}_{2}
\end{gathered}
$$

Reactions are therefore exothermic, than temperature goes to the bathroom increasing since the start of decarbonization (table 3). Depending on the composition of cast iron can also oxidation other elements present in cast iron (Oberg \& Ryffel, 2000).

Is important to note that blower is likely to move through the particular mechanism in the area $\sim 0.7 * \mathrm{D}$ (internal diameter of the furnace), enabling the uniform decarbonization bathroom throughout the oven.

\begin{tabular}{|l|c|c|c|}
\hline Time decarbonization & 5 & 10 & 15 \\
\hline $\mathrm{T}\left({ }^{\circ} \mathrm{C}\right)$ & 1320 & 1480 & 1580 \\
\hline
\end{tabular}

Tab. 3. Increasing the temperature depending on the time of decarbonization

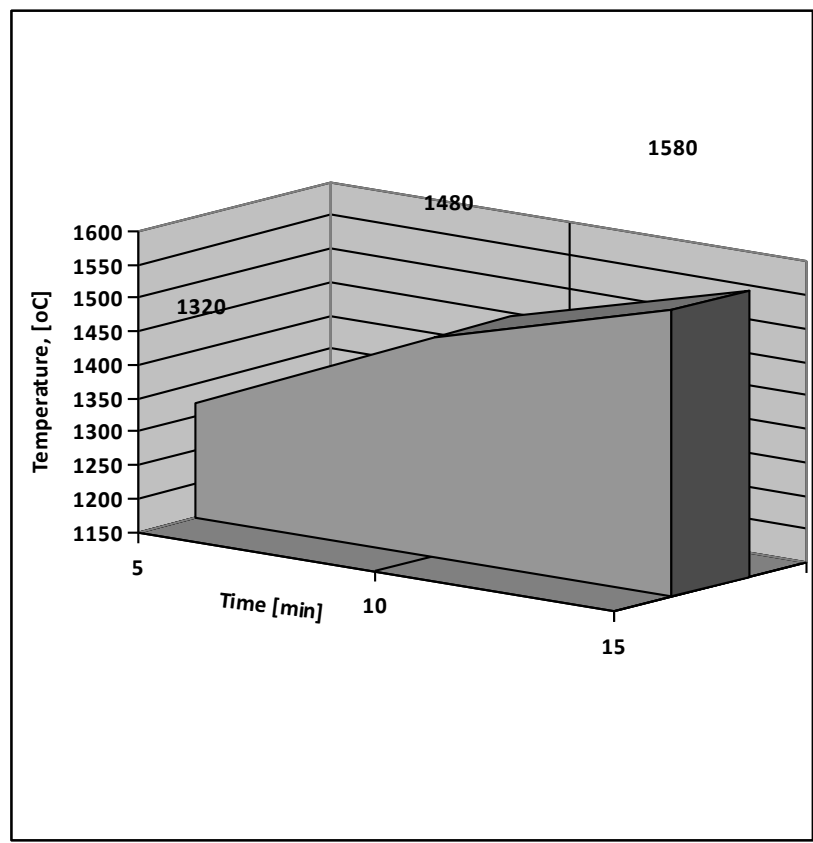

Fig. 4. Temperature $\left({ }^{\circ} \mathrm{C}\right)=\mathrm{f}(\mathrm{t})[\mathrm{min}]$

Due to exothermic reactions during increasing temperature goes up to $1600{ }^{\circ} \mathrm{C}$

\section{ANALYSIS OF \\ THE \\ METAL AFTER DECARBONIZATION}

After the process of 4 loads decarbonization samples were taken and an analysis of their composition in atomic absorber. For each load time of blowing of the oxygen is the amount of carbon determinated in the metal. These data are given in table 4 and chart 2.

\begin{tabular}{|l|c|c|c|c|}
\hline Number of loads & 1 & 2 & 3 & 4 \\
\hline $\begin{array}{l}\text { Blowing time of oxygen } \\
\text { [min] }\end{array}$ & 10 & 15 & 20 & 25 \\
\hline $\begin{array}{l}\text { The amount of Carbon } \\
\text { after decarbonization (\%) }\end{array}$ & 2.4 & 1.4 & 0.8 & 0.3 \\
\hline
\end{tabular}

Tab. 4.Blowing time of oxygen and the amount of Carbon after decarbonization

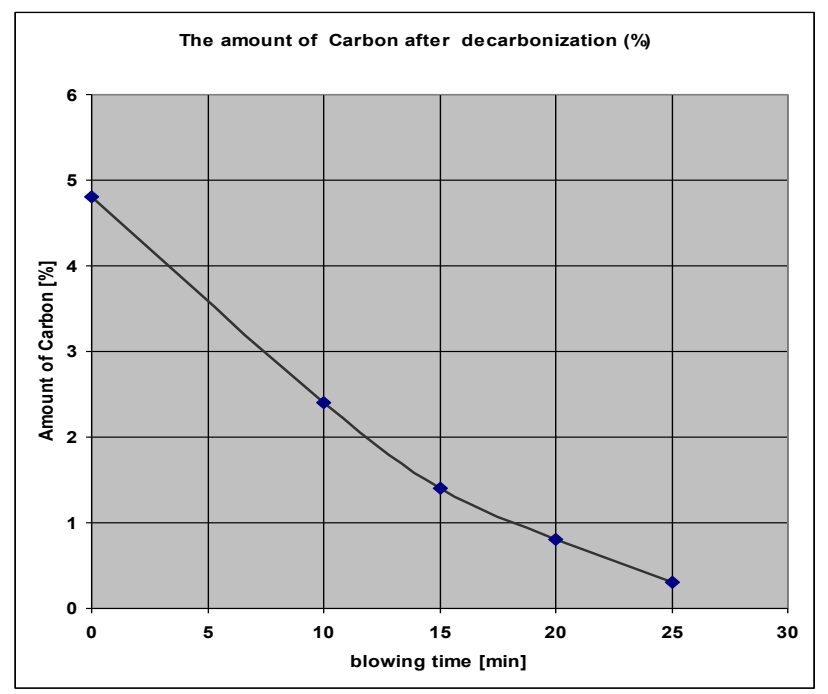

Fig. 5. The change of amount of carbon during the blowing time of oxygen.

\section{CONCLUSION}

After reviewing the results and analysis obtained for four loads of auxiliary furnace can optimalization decarbonization process of the conditions mentioned in the paper.

From the diagram 2, can be determined the minimum time to reach the refining process of cast iron in steel $\left(t_{\min }=13\right.$ min.), that the amount of carbon to be $2 \%$, in such conditions the development process.

For smaller quantities of carbon content in steel, needed the longest blowing time of oxygen, depending on what brand of steel should be produced (i. e. that the amount of carbon to be less than $1.4 \%$, blowing time of oxygen should be longer than $15 \mathrm{~min}$.

In addition to determining the amount of carbon in steel produced depending on the blowing time of oxygen, there is a possibility of adding elements connector (alloys) as: $\mathrm{Cr}, \mathrm{Ni}, \mathrm{V}$, Mo, etc. in the molten metal after decarbonization.

\section{REFERENCES}

Eric, O. (2009). Iron and Steel, ISBN: 0217226418, 9780217226417 New York

Oberg, E; Jones, D. \& Ryffel, H. (2000); Machinery's Handbook (26 ${ }^{\text {th }}$ ed.), ISBN 0-8311-2635-3, New York

Bugayev, K.; Konovalov, Y.; Bychkov, Y.; Tretyakov, E. \& Savin, Ivan V. (2001). Iron and Steel Production. ISBN, 9780894991097, Moskva

Schuman, H. (1985). Metalographie, Leipcig 